\title{
The Antecedents and Consequences of Rapport between Customers and Salespersons in the Tourism Industry
}

\author{
Jinsoo Hwang ${ }^{1}\left({ }^{1}\right.$ Kwang-Woo Lee ${ }^{2, *}$ and Seongseop (Sam) Kim $^{3}$ \\ 1 The College of Hospitality and Tourism Management, Sejong University, 98 Gunja-Dong, Gwanjin-Gu, \\ Seoul 143-747, Korea; jhwang@sejong.ac.kr \\ 2 Department of Tourism Management, College of Economics and Business Administration, Daegu University, \\ Daegu 712-714, Korea \\ 3 School of Hotel and Tourism Management Hong Kong Polytechnic University, Hong Kong, China; \\ sam.kim@polyu.edu.hk \\ * Correspondence: kw.lee@daegu.ac.kr
}

Citation: Hwang, J.; Lee, K.-W.; Kim,

S. The Antecedents and

Consequences of Rapport between Customers and Salespersons in the Tourism Industry. Sustainability 2021, 13, 2783. https://doi.org/10.3390/ su13052783

Academic Editor: Chia-Lin Chang

Received: 10 February 2021

Accepted: 28 February 2021

Published: 4 March 2021

Publisher's Note: MDPI stays neutral with regard to jurisdictional claims in published maps and institutional affiliations.

Copyright: (c) 2021 by the authors. Licensee MDPI, Basel, Switzerland. This article is an open access article distributed under the terms and conditions of the Creative Commons Attribution (CC BY) license (https:// creativecommons.org/licenses/by/ $4.0 /)$.

\begin{abstract}
This study examined the antecedents and consequences of rapport between customers and salespersons in the context of duty-free shops. Specifically, this study proposed six sub-dimensions of service-dominant orientation (i.e., relational, ethical, individuated, empowered, concerted, and developmental interactions). These dimensions have a positive influence on rapport. In addition, rapport is hypothesized to aid in the formation of customer satisfaction and brand preference, which in turn positively affects word-of-mouth communications. Data were collected from 649 Chinese shoppers who have purchased a product in a Korean duty-free shop. In addition, this study employed confirmatory factor analysis to check the adequacy of the measurement items and structural equation modeling to test 11 hypotheses. Data analysis results indicated that five sub-dimensions of servicedominant orientation, excluding individuated interaction, play an important role in the formation of rapport. Furthermore, rapport has a positive effect on customer satisfaction and brand preference, which in turn positively affects word-of-mouth communications. The findings of this study offer valuable insights for managers of duty-free stores into the most effective methods for managing their operations and providing an appropriate blend of products. Furthermore, this paper contributes to theoretical understanding in this area by improving the acceptability of a commonly believed shopper behavior model.
\end{abstract}

Keywords: rapport; service-dominant orientation; duty-free shop; word-of-mouth; satisfaction; brand preference

\section{Introduction}

Shopping accounts for more than half of all aggregated purchases made by Chinese tourists on outbound travel [1]. Shopping continues to be a very important activity for Chinese people travelling abroad during their vacation, so much so, indeed, that in 2013, the Chinese government passed a law that restricts commission-supported visits [1]. People on vacation love to shop, and the opportunity to shop can therefore serve as a great attraction for tourists [2]. The number of duty-free shops in Korea increased from 6 to 13 from 2015 to 2018, an increase that was helped by the growing number of inbound Chinese tourists [3]. The importance of Chinese tourists to the Korean duty-free shop industry is reflected in the fact that their shopping accounts for around 70-80\% of sales [4]. According to the Korea Duty Free Shops Association, South Korea's share of global sales revenues was 10.4\% in 2011, representing the largest market share globally in the duty-free shop market [5]. Major companies in the Korean market accounted for over $90 \%$ of sales [3].

In the service industry, customers' brand preference is reinforced by the positive relationships generated by customer-employee rapport [6]. In the professional service industry, a brand can be influenced by interactions between the service provider and the 
customers [5]. The formation of customer-employee rapport encourages customers to develop preferences for particular brands of duty-free shops and makes it more likely that they will return to those shops again in the future. Customers' interactions with sellers can have a significant impact on their impression of a business. An improvement in the rapport between customers and sellers can therefore lead to positive outcomes for a firm [7]. Despite the importance of shopping for Chinese tourists, there has been little attention paid by researchers to the practices and behaviors that they engage in while shopping.

According to research conducted by Bettencourt and Brown [8], successful interactions result from the capacity of employees' behavior to stimulate customer confidence. Courteous employee behavior can result in the development of customer-employee rapport and positive service experiences for customers [9]. In the study of Hall et al. [10], rapport was found to be closely correlated to relational behaviors between medical students and patients. Recent studies, however, have lacked a nuanced appreciation of the potential for employees to build rapport with customers during their interactions. Specifically, what is needed is a comprehensive understanding of the instruments by which rapport is produced and maintained in a business setting [7]. Such an understanding is important because, as demonstrated by Gremler and Gwinner [11], customer-employee rapport is significantly related to customer satisfaction and loyalty. However, Gremler and Gwinner [11] failed to examine the practices and behaviors that employees use to create that rapport.

Service-dominant orientation (hereafter, S-D orientation) is defined as "An organization's ability to facilitate and enhance mutually beneficial interaction and resource integration processes with individual actors within the service system" [12]. A plausible connection between the six service capabilities and rapport has been suggested in previous studies that have examined S-D orientation. It is therefore important to conduct a detailed examination in order to provide a comprehensive understanding of the elements that contribute to these relational constructs. Therefore, this study examines the importance of S-D orientation in the context of duty-free shops. Specifically, this study aims to explore (1) the influences of the six types of S-D orientation (i.e., relational, ethical, individuated, empowered, concerted, and developmental interactions) on rapport, (2) the effects of rapport on customer satisfaction and brand preference, and (3) the role of customer satisfaction in the formation of brand preference and word-of-mouth communications. This study intends to provide sellers in duty-free shops with the data and tools that they will need to establish and support rapport with customers. By demonstrating the massive potential of rapport to influence key outcome factors that are critical to an organization's success, the present research offers an improved comprehension of customer-employee rapport, which is of great importance for directors and researchers.

Any entity related to duty-free shops can benefit from rapport because of its potential effect on managerially pertinent issues in businesses. The findings of this study provide valuable insights into methods for the effective management of duty-free stores and the provision of an appropriate blend of products. By using these insights, businesses can focus on understanding how rapport can help customers to obtain the most out of their direct service activities. Furthermore, this paper contributes to theoretical understanding in this area by improving the acceptability of a commonly believed shopper behavior model.

\section{Literature Review}

\subsection{Rapport}

Gremler and Gwinner [11] proposed the idea of rapport as a means for describing the nature of the interactions between customers and employees. Rapport can begin to develop following just a single customer-employee interaction [12-14] and is a gauge of the quality of the relationship [11]. Over the years, various definitions of rapport have been proposed. Tickle-Degnen and Rosenthal [15] stated that rapport is "basically having a good interaction amongst people." Dell [16] characterized rapport as "how great customers feel when all is said and done during their interactions with employees". LaBahn [17] characterized rapport as the "customer's discernment that the individual 
relationships have the right 'magnetism' and are charming." Gremler and Gwinner [11] defined rapport as a "personal connection between the two interactants." Catt, Miller, and Schallenkamp [18] characterized rapport as the capacity to develop a relationship founded on harmony and trust and considered it to be a positive and prosocial behavior that is relationally and sufficiently influential to create cohesiveness, diminish risks, and establish social interactions.

What is common about all these definitions is their agreement that the idea of rapport centers on the connection between customer and employee. Basically, measures of rapport provide a decent indication of the quality of the relationship that arises over the course of interactions between customers and employees [14]. Studies about customer service have characterized rapport as a reflection of customers' perceptions of their interactions with employees [11]. Previous studies have characterized rapport as a measure of customers' sentiments about their relationships with sales personnel, especially their level of trust and sense of commitment in terms of continuing that relationship $[17,19]$. The forming of positive interpersonal relationships with employees may have the effect of encouraging customers to continue to support a company with their custom. Without a doubt, a crucial part of the service offering is the relational interaction between customers and employees [20]. Through developing a friendly relationship, the employee can gain an increased understanding of the customer's individual needs and desires. This knowledge gives the employee an opportunity to individualize their service offering and improve quality [20]. This notion of rapport has been described as a precursor of consumer satisfaction [21]. In addition, Coupland [22] has proposed that the development of positive rapport can help in reducing stress and in creating an environment that promotes further interactions and participation.

Previous research on rapport from other disciplines has proposed that relational trust or confidence in an employee's dependability is an important measurement of the customeremployee relationship [23]. Another important measurement is courteous behavior, which has also been considered an effective method for developing rapport [17]. Courteous behavior often incorporates simple actions that render experiences charming or pleasurable for the other individual. For retail employees, these actions may involve wearing a smile, recalling customers by name, utilizing friendly greetings, demonstrating concern for a customer's welfare, participating in courteous behavior, or expressing gratitude toward customers for their patronage [24]. Particularly, information sharing has been shown to be an effective attribute of highly skilled salespeople [25]. In addition, social psychology research has shown that when information is shared, it can prompt increased mimicry and rapport in return [26]. That said, the current study only gives indirect proof that information sharing has an impact on an employee's endeavor to create rapport. Specifically, information sharing by employees is demonstrated when an employee offers advice to the customer or shares information about a specific area that is of interest to the customer. Employees may also make thorough inquiries to better comprehend the customer's needs. In these instances, attention is essentially given to the customer's particular circumstance as opposed to building a personal relationship with the customer. Nevertheless, employees in this scenario intend to accumulate or share data with customers. Consequently, they are indirectly creating rapport.

The development of rapport and improved perceptions of the benefits of the relationship will frequently encourage customers to form a strong commitment toward an organization and to engage in dedicational practices toward it [27]. Customer-employee rapport has customarily been utilized to influence the customer's view of the employee's behavior, which, in turn, directly influences the interaction between customers and employees. Customer-employee rapport, because of its influence on customers' perceptions of a firm and its service delivery, has been recognized as an important issue for service companies to consider [11,19]. As with customer satisfaction, customer-employee rapport refers to customers' subjective evaluation of their emotional state. 
Achieving greater understanding of the role of rapport in high-contact service experiences is essential in order to better equip employees with appropriate capabilities [28]. There are several that can result from doing so [29]. First, there are mental benefits in terms of an increase in confidence and the elimination of tension in the customer-employee relationship. Second, there are social benefits, which arise in the form of close associations and even friendships between customers and employees. Finally, there are financial and customization benefits, including "special treatment benefits" [30], which may involve cost reduction and faster or individualized services.

In spite of the extensive amount of empirical research that has previously been conducted on service relationships and customer evaluations of service quality, other aspects of service interaction remain unexplored. In a retail setting, we define customer-employee rapport as the perceived quality of the relationship and the ways in which this impacts upon communication between the two parties. This study examined customers' perception of rapport as a precursor of service quality. Recent theories on service quality have focused increased attention on quality of interaction as a component of a higher-order concept of service quality [9]. Our reading of previous research in this area prompts us to propose that rapport-building practices are associated with the six components of S-D orientation.

\subsection{Service-Dominant Orientation}

S-D orientation consists of an assortment of operating resources that enable customers and other value network partners to develop their operant resources (e.g., skills and knowledge of an employee) and direct organizational objectives toward strategic capacities that are service driven [31]. Karpen et al. [11] proposed a notion of S-D orientation as being an arrangement of the six abilities, namely, individuated, relational, ethical, empowered, developmental, and concerted interaction capabilities. S-D orientation helps firms in decision-making scenarios by providing competitive advantages and by redesigning and improving the means by which they co-create value with customers [32-34]. S-D orientation thus determines the abilities that firms should prioritize in order to achieve advantages over their competitors, thereby offering good services and shared advancement $[12,31,33,34]$.

In light of the findings of previous studies, this investigation defines S-D orientation as a selection of organizational capabilities that support and enhance the overall direction of resources. From the managerial point of view, S-D orientation gives firms a substantial ability to adjust the organization according to the value network partners. However, improving all hierarchal capabilities simultaneously may be an improbable proposition because of variations in the six capabilities' characteristics and outcomes. All S-D capabilities pertain to individualized substances that cannot be substituted by others. The six capabilities are not inclined to have comparative backgrounds and interests inside a reasoning system of rules [34]. Therefore, we conclude that the six capabilities are not entirely related.

Further detailed research is required to confirm the suggested capabilities and their associations in a measurement model and to enhance our current understanding of the S-D orientation hypothesis with the current network of rules. Additional research is also required to confirm this theory and investigate the consequences of S-D orientation from a network perspective $[34,35]$. We propose that the S-D orientation model and subsequent value perceptions ought to be simultaneously investigated from numerous customer perspectives.

Ultimately, further studies will be required to comprehend how the customer-employee association influences the retail experience in line with the limited existing research on the practices that employees use to create rapport. This study will discuss rapport-building practices recommended by other articles. We will analyze the degree to which they are utilized as a part of retail communications. The precursors to developing rapport, as per Macintosh [36], are the factors that shape a feeling of connectedness and positive influence with respect to service interaction, since studies that have concentrated on the precursors of rapport and its association with service remain few. 
In view of the cited empirical studies, this study theorizes that the presence of S-D orientation between customers and front-line employees affects compatibility toward the service organization. Therefore, concentrating on S-D orientation and the effect of rapport on an organization when S-D orientation is utilized is important. This investigation interprets S-D orientation as a co-creation capability or an association's individuated, relational, w32 or social, ethical/moral, empowered, developmental, and concerted engagement capabilities. These new viewpoints offer significant implications for service industries that have been striving to improve customer loyalty and long-term relationships.

As previously noted, S-D orientation has six components, namely, relational, ethical, individuated, empowered, developmental, and concerted interaction. First, relational interaction capacity is evidentially related to mutual relation because it also has the ability to enrich the association of social and emotional connections with customers [31]. Trust is the most critical variable in a relational interchange. Trust pertains to one's faith in a trade partner's unwavering integrity and credibility, their believability, and their kindheartedness [37].

Employees skilled in relational interaction abilities are able to use them to develop social and emotional associations with customers by improving service methods and procedures [12]. Mavondo and Rodrigo [38] demonstrated that the principal precursor (directly and indirectly) of important relational outcomes for the selling organization (i.e., customer duty, trust, and co-activity) is "social bonding" in the business market. Having the capacity to help customers feel comfortable amidst negotiations and develop rapport will add to the relational interaction on an emotional level [31,33]. Thus, S-D-oriented firms have developed the ability to relate to their customers as service partners, boost discussions, and create a pleasant psychosocial environment for continued progress in the co-creation of value [39].

In addition, a firm that has S-D orientation can enhance the customer-employee relationship through social and emotional associations because they shape the co-creation experience $[12,31,34]$. The components of relational interaction must be considered because social issues cannot be separated from communicational events when investigating types of exchange from the interaction and network perspectives [40]. Boshoff [41] additionally proposed that the nature of the type of interaction plays a vital role in the customeremployee relationship. Furthermore, Gremler, Gwinner, and Brown [42] suggested that a service firm must not only know its customer, but also offer information about themselves to the customer to enhance the strength of the relationship. Along these lines, relational interaction can enhance rapport, such that the following hypothesis is postulated:

\section{Hypothesis (H1) Relational interaction positively influences rapport.}

Second, ethical interaction capacity is the reasonable support offered by a firm with a non-opportunistic customer service process [12,43]. It includes the capacity to act in a reasonably fair and non-opportunistic way toward customers. Ethical interaction can add to trust-based relationships because customers are not purposefully misdirected, manipulated, or misused. In line with the research of Macintosh [36], many studies on the connection between trust and rapport have been conducted. Therefore, we can likely infer that an association exists between ethical capacities and rapport.

Many organizations are concerned with long-standing partnerships. The importance of ethics as the foundational keystone for collaboration and long-standing partnerships has often been included in firms' business strategies [44]. Accordingly, moral affiliation is considered a relevant component of trust-based associations. Conversely, unethical conduct typically leads to the loss of potential income by other ethical businesses or the likelihood of international wholesalers moving their business to other, more transparent markets [43].

For instance, one of the factors that can result in customers' low levels of satisfaction with shopping abroad is the unethical conduct of certain inbound tour operators. This sort of conduct harms a tour destination's image as a money-valued destination [45]. In this 
context, it is reasonable to assume that ethical interaction is a contributing factor in the creation of customer-employee rapport in businesses such as duty-free shops. Therefore, we postulate the following hypothesis.

\section{Hypothesis (H2) Ethical interaction positively influences rapport.}

Third, individuated interaction ability is characterized by an understanding of individual customers' organizational strategies and procedures, service processes, settings of the service, and expected outcomes from the service [12,46,47]. Individuated association centers on the understanding of individual customers. As demonstrated by Sheth, Sisodia, and Sharma [48], the initial stage for building a customer-driven offering based on a service logic relies on a comprehension and understanding of customers' practices. In addition, the more recognizable the service given in terms of customer attitudes, values, and inclination, the better the firm can provide services to customers [36].

Specifically, "having less nervousness and realizing what's in store" may be viewed as a benefit of trust. "Accepting less risk, feeling reliable, and having more confidence" may be considered a form of trust. Therefore, trust in the salesman is one of the essential forerunners of consumer loyalty [7]. Gremler, Rinaldo, and Kelley [49] investigated and bolstered the theory that a positive relationship exists between familiarity and individual contact, which is a component of rapport. Consequently, we propose that a connection is probable between the first capacity and rapport. In this manner, we assume that the sub-dimension of S-D orientation that materializes rapport with customers is individuated interaction. Thus, we propose the following hypothesis.

\section{Hypothesis (H3) Individuated interaction positively influences rapport.}

Fourth, empowered interaction capacity empowers customers in determining the character and elements of service techniques [12,31]. It is defined as the capacity by which firms enable customers to express themselves with regard to the character and elements of the trade. This capacity is concerned with outside-in methods that encourage a cooperative attitude that aids an organization in gaining and understanding new data and information from associates [46]. Bitner, Booms, and Tetreault [50] posited that a feeling of shared understanding is created when service organizations bond with customers by communicating in and welcoming personal exchanges.

Reciprocal self-disclosure will frequently lead to increased interaction because it encourages unbridled communication [51] and has been shown to improve the coordination property for rapport [52]. Customers undoubtedly have more to offer than just moneyrelated resources. Finding ways to attract and prompt value network partners to reciprocate is a potential method of accessing such extra-monetary assets. Doing this enables a firm to benefit from the relationship from a methodological perspective [53]. Firms offer the best platform for customers to achieve their particular value realizations, while customers can help organizations to better meet their inclinations or fundamentals through the firms commitment to customers [54]. The outside-in process aids in jointly developing the customer/organization ability, which will then help the firm to develop new information and data from its network value partners. Conversely, a firm's recognition of its empowered interaction capacity helps it to improve its absorptive expertise [46].

Furthermore, customers' growing need for autonomy and independent control makes it advisable for firms to focus their attention on the potential for co-improvement based on customer-employee encounters [55]. Service organizations should seriously consider empowering employees and giving them flexibility to create, develop, and maintain close relationships. This can help employees to make the right decisions and rectify any problems that arise. This type of behavior from organizations and employees brings about customers' trust, both in particular employees and in the organization as a whole [42]. Therefore, the following hypothesis on the impact of empowered interaction on rapport is proposed. 


\section{Hypothesis (H4) Empowered interaction positively influences rapport.}

Fifth, a concerted interaction ability develops the corresponding and integrated service techniques that integrate customers by encouraging two forms of service, namely, facilitated and coordinated [12]. This study defines concerted interaction as the customer's discernment that employees recognize them and are knowledgeable about their particular needs [56].

Organizations with an S-D orientation perspective are efficient in establishing engagements and resulting service streams within a value network to achieve effectiveness and proficiency [57]. Furthermore, firms should be capable of arranging and synchronizing service programs, such as products or pages, in a manner that enables customers to connect and integrate resources with less effort. In so doing, firms succeed in acting in accordance with customers' value-making processes. Therefore, we posit the following hypothesis.

\section{Hypothesis (H5) Concerted interaction positively influences rapport.}

Lastly, developmental interaction ability enables customers to hold specific information and expertise development with service strategies [12]. Employees equipped with this ability are able to offer detailed knowledge and expertise to customers. Empowered interaction refers to the capacity to retain and adjust to input from the outside [31]. Whereas empowered interaction ability concerns the ability to hold and change in accordance with outside input, developmental interaction capacity has to do with being keen to offer internal information and expertise to outside partners [31,56]. Firms who share their expertise and informational resources enhance the capacities of their co-creation partners [56]. Employees are encouraged not to hover over customers or use pressure tactics to generate sales.

In addition, employees should avoid talking among themselves in the presence of customers. The near universal availability of data renders the investigation of this area straightforward for customers. However, this condition is good for the overall population when everything is taken into account [34]. Ganesan and Hess [58] demonstrated that the individual customer's capacity and intention to adhere to promises is a salient indicator of customer loyalty toward a selling enterprise when compared with that enterprise's capacity and intent to keep their guarantees.

In the field of hospitality, performance is the assurance of the capacity of the hospitality organization in supplying good quality services, such as infrastructure and resources in addition to employee skills and expertise [59]. Thus, training is vital to enable staff to acquire the expertise and skills necessary for managing their areas of responsibility, for example, the products and services that customers may enquire about. Staff should also be trained to have a strong work commitment. Accordingly, expanding developmental interaction could contribute to rapport. Therefore, the following hypothesis is proposed.

\section{Hypothesis (H6) Developmental interaction positively influences rapport.}

\subsection{Customer Satisfaction}

Customer satisfaction has widely been viewed as one of the principal determinants of long-term customer behavior. The more satisfied a customer is, the greater the likelihood of maintaining their custom and the more likely it is that the firm will benefit from positive word of mouth exchanges [60]. There is therefore good reason for companies to concentrate on improving customer satisfaction rates.

Previous studies have found that a customer's opinions on employees' relational practices (e.g., recognition, care, business fellowship, listening behavior, and consumer orientation) can influence their level of satisfaction with the service they receive [61]. Rapport is deemed to directly influence customer satisfaction because of the important role it plays in employee relational practices. In addition, rapport captures the relational components of the service delivery process and is a critical element of customer satisfaction [62]. 
Satisfied customers tend to remain loyal to the service business [63] and become effective participants in positive word-of-mouth marketing [64].

In light of earlier research $[11,30]$, rapport is theorized to positively affect customer satisfaction. The logic behind postulating this connection between rapport and customer satisfaction is twofold. First, the closer the relationship, the better the understanding of the special needs and desires of employees. Second, the customer develops a precise understanding of the firm's capacities [11]. This study investigates the impact of rapport on customer satisfaction. In light of our review of previous studies on this topic, the following hypothesis is proposed.

\section{Hypothesis (H7) Rapport positively influences customer satisfaction.}

\subsection{Brand Preference}

Brand is a particularly distinguishable component of a product or item and plays a crucial role in determining customers' decisions about which items to purchase $[65,66]$. For instance, even though customers may be happy with their practical estimation of an item, they may not buy that item again if it is not their preferred brand [67,68]. Hellier et al. [69] characterized "brand preference" as the degree to which a customer supports the assigned service given by a specific organization.

Customers create brand preferences to decrease the intricacy of the buying decision process [70]. The process of shaping brand preferences includes the stage at which consumers are introduced to numerous brands; this is then followed by an intricate buying choice process. Customers frequently omit certain brands from memory. Among those that they retain in their memory are those brands that they might consider obtaining later on [71]. From the business point of view, the main difficulty lies in maintain customers' preference for a particular brand in contexts where they are constantly being presented with opportunities to sample items from competing brands [72]. The underlying rationale behind consumers' changing brand preferences is their continuous search for brands that offer high-quality products or services.

Various studies have observed a relationship between consumer loyalty and brand preference [11,73]. The association between the two is dependent on increased confidence and decreased anxiety. This association is especially vital for professional services, where customers consider the process of assessing the service troublesome [74]. Lastly, it is widely acknowledged that consumer loyalty drives positive brand preference. However, there have also been studies that have demonstrated that this connection may, in certain circumstances, be inconsistent $[61,75]$. In sum, consumers' brand preferences can be altered as a result of their service experience. Changes in consumers' preferences result from the degree to which employees follow up on their role expectations and succeed in engendering positive customer-employee relationships [76].

With regard to professional service suppliers, customers cultivate brand preferences for the main aspects of the brand, such as dependability and adaptability. The level of the bond offers a fair indication of the quality and forms of the relationship amid exchanges between customers and employees [14]. Studies in this area have characterized the customer-employee bond or rapport as mirroring customers' views of the pleasantness of their exchanges with the employees of a business and the extent to which these exchanges result in the creation of positive customer-employee connections [11]. The customeremployee bond is an important element of brand preference and has been utilized to capture the customer's view of employee conduct that specifically influences the exchanges between the two parties.

Organizations need to recognize the factors that influence brand preference and develop strategies that take these factors into account. There is thus a need to investigate how the customer-employee connection influences consumers' brand preferences [77]. In spite of the importance of brand preference, no investigation into its significance has been conducted in the context of the duty-free shop industry $[78,79]$. This study defines brand 
preference and analyzes its effect on outcome variables. It begins with an evaluation of the impact of customer-employee rapport and its potential consequences for brand preferences.

Hypothesis (H8) Rapport positively influences brand preference.

In relation to brand preference, a duty-free shop brand that has established good rapport between customers and employees will clearly prefer customers who utilize "brands" in choosing where to buy. Moreover, purchasers who have a significant, solid association with employees at a duty-free shop will verbally spread positive reviews with others. Following this rationale, this study conjectures that rapport is emphatically connected with brand inclination and that consumer satisfaction decidedly influences brand preferences.

\section{Hypothesis (H9) Customer satisfaction positively influences brand preferences.}

\subsection{Word-of-Mouth Communications}

Friends, relatives, and colleagues have an incredible impact on the information that is spread about other individuals [80]. As per Westbrook [81], word-of-mouth is "an informal exchange or communication directed at different buyers about the possession, use, or attributes of specific merchandise and ventures." Informal exchange by word-of-mouth is a vital factor in determining how consumers evaluate and choose new items or services [82]. Informal exchange by word-of-mouth is the most cost-effective method of endorsing items and services from a business point of view.

Word-of-mouth communications are, according to Brown et al. [64], the most important result of customer-business interactions. Positive word-of-mouth exchanges have a massive impact in service settings. This is because services cannot be tested before buying [83]. Companies cannot control or manipulate informal exchanges by word-of-mouth. Therefore, customers view these exchanges as reliable, and this in turn drives their enthusiasm as potential customers $[84,85]$. Researchers who study information exchange by word-of-mouth recognize that it functions as another source of recommendation, which can impact a shopper's decision-making process and exert an influence over their assessment of items and buying choices [60].

Research has confirmed that informal exchange by word-of-mouth plays a critical role in influencing customer decision making as well as post-purchase opinions [86]. Generally, customer satisfaction is regarded as an indicator of word-of-mouth exchanges [87]. The authors also believe that satisfied customers will repurchase and spread positive wordof-mouth opinions about the advantages of the products that they buy. De Matos and Rossi [88] have demonstrated the importance of loyalty, satisfaction, and duty. Likewise, word-of-mouth exchanges are reproduced in buyer networks [89]. Thus, we propose that a positive relationship exists between customer satisfaction and word-of-mouth exchanges.

Hypothesis (H10) Customer satisfaction positively influences word-of-mouth exchanges.

Furthermore, $\mathrm{b}$ rand inclination is vital as a key indicator of informal exchanges by word-of-mouth. After using products or services, consumers form their attitudes regarding the evaluated brand $[90,91]$. Since some consumers concentrate on specific brands, brands still play a more significant role than quality in the purchasing process [92]. A positive brand experience contributes toward a consumer's preference for a specific brand $[69,93]$. Thus, brand preference relies on previous experiences [94]. Therefore, if consumers have a preference for any brand, they will convey positive opinions about the product via word-of-mouth to other consumers based on their previous experiences [95]. It is thus necessary to understand the relationship between brand preference and word-ofmouth exchanges in order to enhance brand preference and to explore its consequences in the duty-free market. For instance, Kim, Han, and Lee [96] demonstrated that positive informal exchange by word-of-mouth in the hotel industry is the most important type of communication. Zhang and Bloemer [97] also demonstrated that customers who are 
profoundly dedicated to a specific brand in the retail industry are likely to spread positive word-of-mouth opinions about it to others. In addition, Kim, Magnini, and Singal [98] have recently demonstrated that the impact of brand inclination on positive word-of-mouth communications is essential for the restaurant industry.

Unfortunately, there have been few studies to date that have focused on the potential to form policies for the rewarding of positive word-of-mouth communications or that have expected that customer satisfaction will prompt such practices. Informal exchanges by word-of-mouth from a current customer to a potential customer are a dependable technique for stimulating new business for companies. These referrals might be supported through the development of relational bonds or rapport between employees and customers in the service setting. This study proposes that brand preference can significantly impact positive word-of-mouth exchanges. On the basis of the foregoing literature review, the following hypothesis is proposed.

Hypothesis (H11) Brand preference positively influences word-of-mouth marketing.

Based on the 11 hypotheses presented in the theoretical background, the following research model is presented in Figure 1.

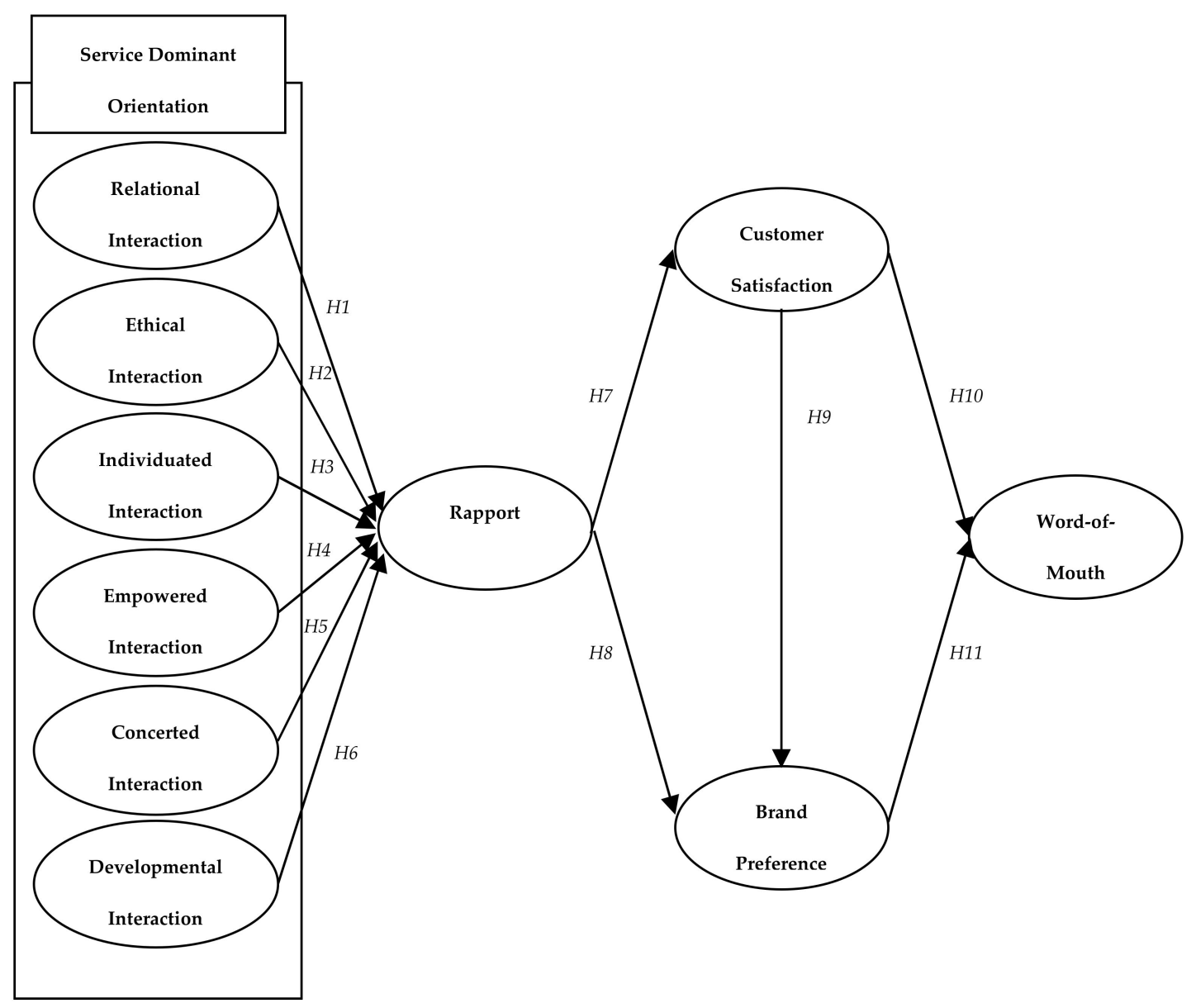

Figure 1. Proposed conceptual model.

\section{Methodology}

\subsection{Measurement}

This study used the following measurement items that were confirmed reliable and valid by existing studies to measure the proposed concept. First, S-D orientation was measured using 24 items from Karpen et al. [12,31]. Second, rapport was measured with 
six items adapted from previous studies [11,99]. Customer satisfaction was measured with three items used from Hennig-Thurau et al. [30] and Oliver [100]. Brand preference was measured with three items derived from previous studies [69,101]. Measures for word-of-mouth were extracted from previous research [30]. All items were measured using a five-point Likert-type scale, anchored between "strongly disagree" [1] and "strongly agree" [5].

\subsection{Data Collection}

For data collection, an online panel survey method was used to approach the target population. The survey was conducted by an online panel survey company, which is one of the largest online panel survey companies in mainland China. It has more than 2.6 million panel members. An online panel survey has more benefits compared with traditional survey methods in terms of selection of targeted samples, cost reduction, and timely data collection [102]. However, an online panel survey is also vulnerable to certain limitations, such as the lack of participation by reliable/competent respondents and the absence of the types of explanation that interviewees can provide [103]. In addition, this study allowed respondents to pass on questions that were difficult to answer.

Three screening questions were employed to guarantee the validity of the data. First, only respondents who were at least 18 years old were invited to participate in this survey. Second, they had to have visited Korea on at least one occasion. Third, they had to have had an experience of purchasing a product in a Korean duty-free shop during their trip. A check was carried out to identify whether the respondents were qualified to participate in the survey. On the front page, an open-ended question was designed to prompt age, while another open-ended question that requested the survey taker's birth year was located in a later section of the survey. If there was a gap between the present age and present year minus the birth year, the participant was ruled out and considered an untrustworthy respondent whose participation was motivated by the prospect of receiving a gift as a reward for participating in the survey. Likewise, participants were asked twice in the first and last pages about the number of times they had visited Korea to verify whether their answers were correct. A total of 1000 respondents participated in the online panel survey. However, 351 respondents were omitted because of missing data and a Mahalanobis distance check. Consequently, a total of 649 questionnaires were employed for further analysis.

\section{Results}

\subsection{Descriptive Statistics}

Among the survey participants, $43.9 \%$ of respondents were male, and the mean age of respondents was 33.1 years. In terms of respondents' level of education, the highest number held a bachelors' degrees $(63.0 \%)$. In addition, most respondents were married $(84.6 \%)$. In terms of occupation, $64.9 \%$ were company employees, followed by professionals $(16.8 \%)$. Lastly, the largest annual household income category was noted to be in a range of US $\$ 21,601$ to US $\$ 27,770$ (23.4\%). Table 1 provides the detailed profile of the respondents.

Table 1. Profile of survey respondents $(n=649)$.

\begin{tabular}{lcc}
\hline Variable & $n$ & Percentage \\
\hline Gender & 285 & \\
Male & 364 & 43.9 \\
Female & & 56.1 \\
Education level & 146 & 22.5 \\
High school diploma & 32 & 4.9 \\
Associate's degree & 409 & 63.0 \\
Bachelor's degree & 62 & 9.6 \\
Graduate degree & & \\
\hline
\end{tabular}


Table 1. Cont.

\begin{tabular}{lcc}
\hline Variable & $n$ & Percentage \\
\hline Marital status & & \\
$\quad$ Single & 99 & 15.3 \\
$\quad$ Married (including divorced and widow/widower) & 549 & 84.6 \\
Occupation & 421 & 64.9 \\
$\quad$ Company employee & 42 & 6.5 \\
Self-employed & 16 & 2.5 \\
Sales/service & 9 & 1.4 \\
Student & 44 & 6.8 \\
Civil servant & 109 & 16.8 \\
Professional & 8 & 1.3 \\
Other & & \\
Yearly household income & 127 & 19.6 \\
Less than US $\$ 16,601$ & 121 & 18.6 \\
US $\$ 16,601 \sim$ US $\$ 21,600$ & 152 & 23.4 \\
US\$21,601 US\$27,770 & 148 & 22.8 \\
US\$27,771 US\$37,000 & 101 & 15.6 \\
More than US $\$ 37,000$ & & \\
Mean age $=33.10$ years old & & \\
\hline
\end{tabular}

Table 2 shows the profile of their travel characteristics. With regard to the total number of trips to Korea, the highest frequency reported was twice $(n=248,38.2 \%)$. In addition, more than $50 \%$ of respondents had visited a Lotte duty-free shop $(n=371,57.2 \%)$. Since duty-free shop businesses have been licensed and managed by international global department store companies in South Korea, their brand values are highly recognized by inbound customers [104]. In terms of the number of duty-free shop visits, most respondents visited duty-free shops twice during their visit $(n=298,45.9 \%)$. The main purpose of travel was leisure $(n=579,89.2 \%)$. With regard to respondents' length of stay in Korea, the most had stayed for three nights $(n=212,32.7 \%)$. When respondents were asked about a travel companion, they reported as travelling alone $(n=43,6.6 \%)$, with a friend $(n=236,36.4 \%)$, with an association or company $(n=33,5.1 \%)$, and with family or relatives $(n=337,51.9 \%)$. Lastly, the average amount that respondents spent on shopping was US\$2780.

Table 2. Profile of the survey respondents' travel characteristics $(n=649)$.

\begin{tabular}{lcc}
\hline Variable & $n$ & Percentage \\
\hline How many times have you visited Korea including this tour? & & \\
One time & 146 & 22.5 \\
Two times & 248 & 38.2 \\
Three times & 146 & 22.5 \\
More than three times & 109 & 16.8 \\
Which duty-free shop did you visit during this visit? & & 57.2 \\
Lotte duty-free shop & 371 & 28.4 \\
Silla duty-free shop & 184 & 7.2 \\
AK duty-free shop & 47 & 6.5 \\
Donghwa duty-free shop & 42 & 0.8 \\
Walkerhill duty-free shop & 5 & \\
How many times have you visited the duty-free shop (you & & 20.5 \\
mentioned above) during this tour? & & 45.9 \\
One time & 133 & 24.5 \\
Two times & 298 & 4.0 \\
Three times & 159 & 3.9 \\
Four times & 26 & 1.3 \\
Five times & 25 & \\
More than five times & 8 & \\
\hline
\end{tabular}


Table 2. Cont.

\begin{tabular}{lcc}
\hline Variable & $n$ & Percentage \\
\hline What is the main purpose of this tour for you? & 579 & 89.2 \\
Leisure & 25 & 3.9 \\
Business & 8 & 1.2 \\
To meet friends or relatives & 37 & 5.7 \\
Shopping & 7 & \\
How long did you stay in Korea? & 71 & 1.1 \\
One night & 212 & 32.7 \\
Two nights & 191 & 29.4 \\
Three nights & 168 & 25.9 \\
Four nights & & \\
More than four nights & 43 & 6.6 \\
With whom did you travel? & 236 & 36.4 \\
Alone & 33 & 5.1 \\
Friend(s) & 337 & 51.9 \\
Association or Company & & \\
Family or Relatives & & \\
How much did you spend on shopping? Average = US\$2780 (SD = US\$6473) & \\
\hline
\end{tabular}

Note: SD = Standard deviation.

\subsection{Measurement Model}

Confirmatory factor analysis was conducted to assess the adequacy of the measurement items using Amos. The measurement model consisted of 10 constructs with 39 measurement items. The factor loadings of the manifest variables on their respective latent variables were equal to or greater than 0.736 and significant at $p<0.001$ (Table 3 ). As indicated in Table 3, the CFA model presented a very good fit with the data $\left(\chi^{2}=1165.030, d f=620\right.$, $\chi^{2} / d f=1.879, \mathrm{NFI}=0.940, \mathrm{IFI}=0.971, \mathrm{CFI}=0.971, \mathrm{TLI}=0.965$, and RMSEA $\left.=0.037\right) . \mathrm{In}$ addition, the composite reliabilities of the constructs ranged from 0.856 to 0.903 , which exceeded the threshold value of 0.70 [105].

Table 3. Confirmatory factor analysis: Items and loadings.

\begin{tabular}{lc}
\hline \multicolumn{1}{c}{ Construct and Scale Items } & $\begin{array}{c}\text { Standardized } \\
\text { Loading }\end{array}$ \\
\hline $\begin{array}{l}\text { Service Dominant Orientation } \\
\text { Relational interaction }\end{array}$ & 0.842 \\
$\quad$ The salesperson made me feel at ease. & 0.799 \\
The salesperson tried to establish a mutual relation with me. & 0.807 \\
The salesperson encouraged two-way communication with me. & 0.816 \\
The salesperson showed genuine interest in engaging me. & 0.794 \\
Ethical interaction & 0.788 \\
The salesperson did not try to take advantage of me. & 0.805 \\
The salesperson did not pressure me in any way. & 0.801 \\
The salesperson did not mislead me in any way. & 0.759 \\
The salesperson did not try to manipulate me. & 0.783 \\
Individuated interaction & 0.770 \\
The salesperson made an effort to understand my individual needs. & 0.779 \\
The salesperson was sensitive to my individual situation. & \\
The salesperson made an effort to find out what kind of offering is most & \\
helpful to me. & 0.805 \\
The salesperson sought to identify my personal expectations. & 0.785 \\
Empowered interaction & 0.736 \\
The salesperson let me interact with him/her in my preferred way. & 0.776 \\
The salesperson encouraged me to customize my shopping experience. & \\
The salesperson allowed me to control my shopping experience. & \\
The salesperson invited me to share my own ideas or suggestions. & \\
\hline
\end{tabular}


Table 3. Cont.

\begin{tabular}{|c|c|}
\hline Construct and Scale Items & $\begin{array}{l}\text { Standardized } \\
\text { Loading }\end{array}$ \\
\hline \multicolumn{2}{|l|}{ Concerted interaction } \\
\hline The salesperson worked together seamlessly when selling products. & 0.754 \\
\hline The salesperson acted as one unit when dealing with me. & 0.785 \\
\hline $\begin{array}{l}\text { The salesperson provided messages to me that were consistent with } \\
\text { each other. }\end{array}$ & 0.775 \\
\hline $\begin{array}{l}\text { The salesperson ensured he/she had smooth procedures for interacting } \\
\text { with me. }\end{array}$ & 0.798 \\
\hline \multicolumn{2}{|l|}{ Developmental interaction } \\
\hline The salesperson shared useful information with me. & 0.771 \\
\hline The salesperson helped me become more knowledgeable. & 0.781 \\
\hline The salesperson provided me with the advice I needed. & 0.806 \\
\hline The salesperson offered me expertise that I could learn from. & 0.809 \\
\hline \multicolumn{2}{|l|}{ Rapport } \\
\hline I enjoyed interacting with the salesperson. & 0.831 \\
\hline I felt warm-hearted in the relationship with the salesperson. & 0.788 \\
\hline I was comfortable interacting with the salesperson. & 0.772 \\
\hline I felt like there was a bond between myself and the salesperson. & 0.745 \\
\hline $\begin{array}{l}\text { I looked forward to seeing the salesperson when I shop at the duty-free } \\
\text { shop next time. }\end{array}$ & 0.753 \\
\hline I wanted to have a close relationship with the salesperson. & 0.791 \\
\hline \multicolumn{2}{|l|}{ Customer satisfaction } \\
\hline I was satisfied with this duty-free shop. & 0.823 \\
\hline I was pleased to visit this duty-free shop. & 0.803 \\
\hline I was delighted with this duty-free shop. & 0.859 \\
\hline \multicolumn{2}{|l|}{ Brand preference } \\
\hline $\begin{array}{l}\text { When I want to shop, I very often consider this duty-free shop a } \\
\text { viable choice. }\end{array}$ & 0.891 \\
\hline $\begin{array}{l}\text { This duty-free shop meets my shopping needs better than other } \\
\text { comparable duty-free shops. }\end{array}$ & 0.869 \\
\hline $\begin{array}{l}\text { I am interested in this duty-free shop more than in other comparable } \\
\text { duty-free shops. }\end{array}$ & 0.801 \\
\hline \multicolumn{2}{|l|}{ Word-of-mouth } \\
\hline I said positive things about this duty-free shop to others. & 0.822 \\
\hline I recommended this duty-free shop to others. & 0.861 \\
\hline I encouraged others to visit this duty-free shop. & 0.849 \\
\hline Goodness-of-fit statistics: $\chi^{2}=1165.030, d f=620, \chi^{2} / d f=1.879, p<0.001$, & \\
\hline $\mathrm{NFI}=0.940, \mathrm{IFI}=0.971, \mathrm{CFI}=0.971, \mathrm{TLI}=0.965, \mathrm{RMSEA}=0.037$ & \\
\hline
\end{tabular}

The average variance extracted (AVE) from all of the constructs was more than the recommend value of 0.50 [106] (Table 4). This result suggests an acceptable convergent validity. Lastly, discriminant validity was verified by comparing the values of the squared correlation of the paired constructs with the AVE values of each construct [107]. The condition was satisfactory, except for (1) ethical interaction and individuated interaction and (2) ethical interaction and empowered interaction. For these exceptions, a $\chi^{2}$ difference between the combined and uncombined models was calculated. Results indicated that the $\chi^{2}$ differences for (1) ethical interaction and individuated interaction and (2) ethical interaction and empowered interaction were statistically significant at $p<0.001$ under one degree of freedom. This finding suggests that discriminant validity was well established. 
Table 4. Descriptive statistics and associated measures.

\begin{tabular}{|c|c|c|c|c|c|c|c|c|c|c|c|c|c|}
\hline & $\begin{array}{l}\text { No. of } \\
\text { Items }\end{array}$ & $\begin{array}{l}\text { Mean } \\
\text { (SD) }\end{array}$ & AVE & (1) & (2) & (3) & (4) & (5) & (6) & (7) & (8) & (9) & (10) \\
\hline $\begin{array}{l}\text { (1) Relational } \\
\text { interaction }\end{array}$ & 4 & $\begin{array}{c}4.15 \\
(0.92)\end{array}$ & 0.666 & $0.889^{a}$ & $0.733^{b}$ & 0.755 & 0.734 & 0.769 & 0.784 & 0.766 & 0.794 & 0.676 & 0.631 \\
\hline $\begin{array}{l}\text { (2) Ethical } \\
\text { interaction }\end{array}$ & 4 & $\begin{array}{c}4.07 \\
(0.96)\end{array}$ & 0.635 & $0.537^{c}$ & 0.874 & 0.788 & 0.799 & 0.713 & 0.785 & 0.748 & 0.750 & 0.661 & 0.626 \\
\hline $\begin{array}{l}\text { (3) Individuated } \\
\text { interaction }\end{array}$ & 4 & $\begin{array}{c}4.13 \\
(0.89)\end{array}$ & 0.597 & 0.570 & 0.621 & 0.856 & 0.736 & 0.732 & 0.745 & 0.728 & 0.782 & 0.694 & 0.670 \\
\hline $\begin{array}{l}\text { (4) Empowered } \\
\text { interaction }\end{array}$ & 4 & $\begin{array}{c}4.11 \\
(0.88)\end{array}$ & 0.602 & 0.539 & 0.638 & 0.542 & 0.858 & 0.725 & 0.705 & 0.744 & 0.801 & 0.722 & 0.672 \\
\hline $\begin{array}{l}\text { (5) Concerted } \\
\text { interaction }\end{array}$ & 4 & $\begin{array}{c}4.09 \\
(0.94)\end{array}$ & 0.606 & 0.591 & 0.508 & 0.536 & 0.526 & 0.860 & 0.749 & 0.743 & 0.796 & 0.733 & 0.650 \\
\hline $\begin{array}{l}\text { (6) Developmental } \\
\text { interaction }\end{array}$ & 4 & $\begin{array}{c}4.12 \\
(0.95)\end{array}$ & 0.627 & 0.615 & 0.616 & 0.555 & 0.497 & 0.561 & 0.871 & 0.763 & 0.738 & 0.732 & 0.682 \\
\hline (7) Rapport & 6 & $\begin{array}{c}4.07 \\
(0.92)\end{array}$ & 0.609 & 0.587 & 0.560 & 0.530 & 0.554 & 0.552 & 0.582 & 0.903 & 0.785 & 0.680 & 0.647 \\
\hline $\begin{array}{l}\text { (8) Customer } \\
\text { satisfaction }\end{array}$ & 3 & $\begin{array}{c}4.23 \\
(0.95)\end{array}$ & 0.687 & 0.630 & 0.563 & 0.612 & 0.642 & 0.634 & 0.545 & 0.616 & 0.868 & 0.709 & 0.710 \\
\hline $\begin{array}{l}\text { (9) Brand } \\
\text { preference }\end{array}$ & 3 & $\begin{array}{c}4.11 \\
(0.88)\end{array}$ & 0.730 & 0.457 & 0.437 & 0.482 & 0.521 & 0.537 & 0.536 & 0.462 & 0.503 & 0.890 & 0.732 \\
\hline $\begin{array}{l}\text { (10) } \\
\text { Word-of-mouth }\end{array}$ & 3 & $\begin{array}{c}4.19 \\
(0.86)\end{array}$ & 0.713 & 0.398 & 0.392 & 0.449 & 0.452 & 0.423 & 0.465 & 0.419 & 0.504 & 0.536 & 0.899 \\
\hline
\end{tabular}

Note 1: $\mathrm{SD}$ = Standard Deviation, AVE = Average Variance Extracted. Note 2: a. composite reliabilities are along the diagonal, b. correlations are above the diagonal, c. squared correlations are below the diagonal.

\subsection{Structural Model}

Figure 2 shows the results of structural equation modeling (SEM). The overall fit indices statistically supported the fit of the proposed structural model. $\left(\chi^{2}=1261.549\right.$, $\mathrm{df}=654, \chi^{2} / \mathrm{df}=1.929, \mathrm{NFI}=0.935, \mathrm{IFI}=0.968 ; \mathrm{CFI}=0.968 ; \mathrm{TLI}=0.963$, and RMSEA $=0.038$ The results of SEM analysis statistically supported 10 of 11 hypotheses at the 0.05 level. Specifically, relational $(\beta=0.213, p<0.05)$, ethical $(\beta=0.145, p<0.05)$, empowered $(\beta=0.170, p<0.05)$, concerted $(\beta=0.259, p<0.05)$, and developmental $(\beta=0.246, p<0.05)$ interactions positively affect rapport, so Hypotheses $1,2,4,5$, and 6 were supported. However, there is no significant relationship between individuated interaction and rapport $(\beta=0.288, p>0.05)$. Thus, Hypothesis 3 was not supported. In addition, rapport has a positive effect on customer satisfaction $(\beta=0.843, p<0.05)$ and brand preference $(\beta=0.466$, $p<0.05)$. Hence, Hypotheses 7 and 8 were supported. Customer satisfaction helps to form brand preference $(\beta=0.316, p<0.05)$ and word-mouth $(\beta=0.112, p<0.05)$, so Hypotheses 9 and 10 were supported. Lastly, there is a positive relationship between brand preference and word-of-mouth $(\beta=0.837, p<0.05)$. Therefore, Hypothesis 11 was supported. 


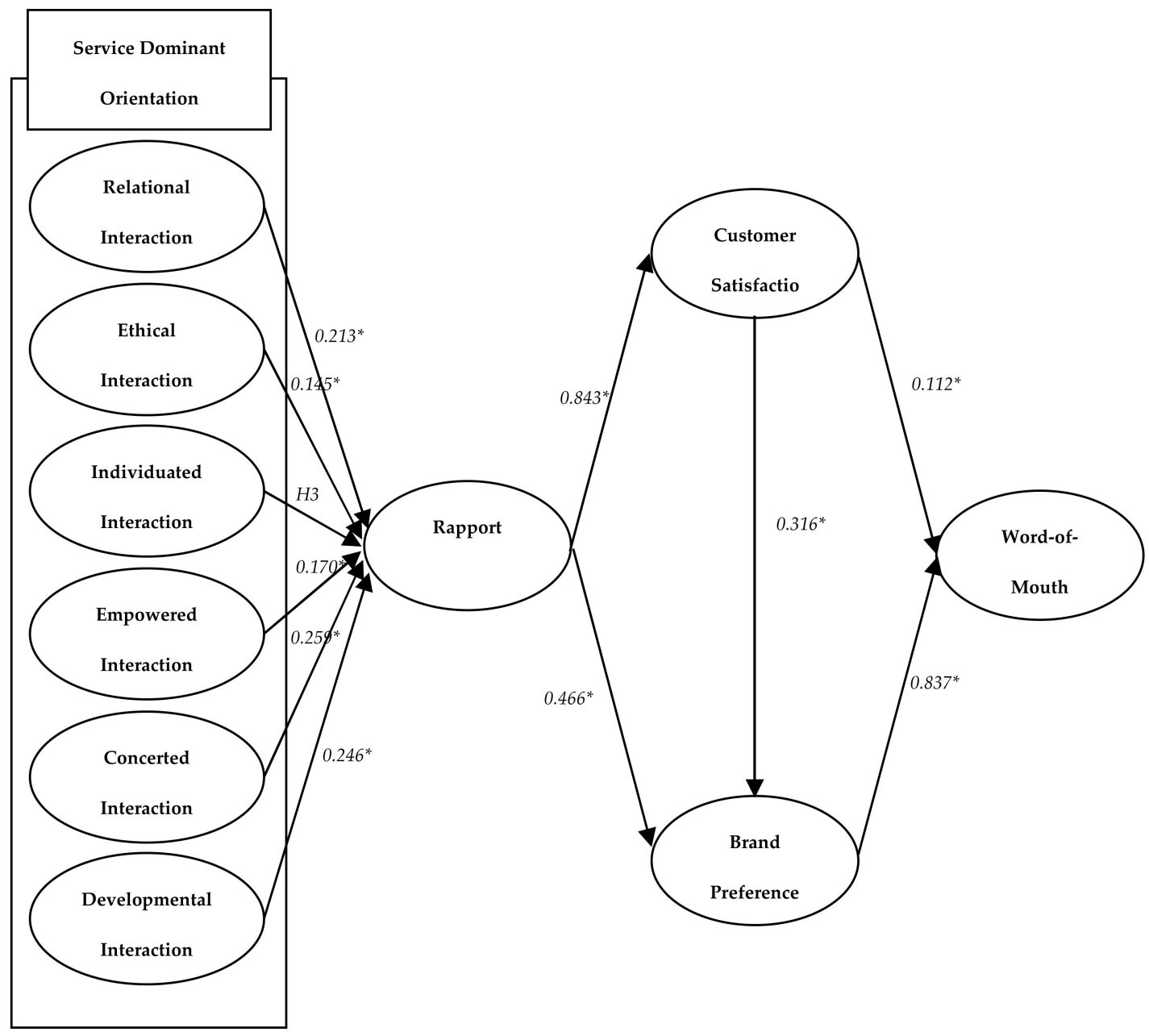

Figure 2. Standardized theoretical path coefficients.

\section{Discussion}

This study aimed to identify the importance of S-D orientation in the context of duty-free shops. Specifically, this study considered six dimensions of S-D orientation (i.e., relational, ethical, individuated, empowered, concerted, and developmental interactions). These interactions were proposed to have a significant effect on rapport. In addition, rapport was hypothesized to positively affect customer satisfaction, which in turn has a positive influence on brand preference and word-of-mouth communication. To test the 11 proposed hypotheses, data were collected from 649 Chinese tourists who had purchased a product in Korean duty-free shops. Based on the results of data analysis, this study suggested that duty-free shop managers should focus on the five dimensions of S-D orientation (i.e., relational, ethical, empowered, concerted, and developmental interactions), which positively affect rapport between customers and sellers. Doing so offers the potential to boost customer satisfaction, brand preference, and word-of-mouth marketing.

In the history of S-D orientation research, relational interaction has consistently been considered a critical factor in the evaluation of overall employee services $[42,108]$. While previous studies have suggested the importance of relational interaction in the service industry, this study is the first to apply the concept of relational interaction to the context of duty-free shops. The significance of ethical interaction has consistently been confirmed in various fields of study $[43,57]$. The results show that ethical interaction has a significant impact on the maintenance of long-standing relationships with customers. Previous studies have also suggested the importance of employee honesty in the formation of positive relationships between employees and customers $[109,110]$. As previously mentioned, empowered interaction plays an important part in the service industry [55]. The findings of 
the current study also support this argument. In addition to this, previous studies that have focused on concerted interaction [12,31] have also shown it to be a critical factor influencing the relationship between employees and customers. The current study identified the relationship between concerted interaction and rapport and found that concerted interaction is an important predictor of rapport. This study replicated and extended previous findings by establishing the relationship between developmental interaction and rapport in the context of duty-free shops. The results of this study are consistent with those of previous studies [11,42], which suggest that rapport is a crucial factor that influences outcome variables, such as customer satisfaction, brand preference, and word-of-mouth exchanges. The relationship between brand preference and word-of-mouth has been consistently confirmed by Kim, Han, and Lee [96] and Zhang and Bloemer [97].

\section{Conclusions}

\subsection{Theoretical Implications}

First, the results of data analysis showed that relational interaction was an important predictor of rapport between customers and salespeople. Its findings have verified and extended our existing understanding of a theoretical relationship (i.e., the positive relationship between relational interaction and rapport) by empirically identifying the effect of relational interaction on rapport in the context of duty-free shops. The finding can be interpreted as implying that when a salesperson makes customers feel at ease, customers perceive that they have a good relationship with that salesperson.

Second, the results of the data analysis revealed that ethical interaction plays an important role in the formation of rapport. The focus of our study was on examining the effect of ethical interaction on rapport in the context of duty-free shops. It showed that when a salesperson treats customers ethically, customers are more likely to be comfortable interacting with that salesperson. Thus, the salesperson should not deceive customers to boost his or her sales performance.

Third, contrary to our expectation, Hypothesis 3, which proposed the effect of individuated interaction on rapport, was not statistically supported. The findings of this study in this regard are different from those of previous studies [31,49]. Due to the nature of duty-free shops, the interactions of most employees tend to be with foreign tourists rather than regular customers, and for this reason, it is more difficult for employees to satisfy their individual needs. It appears, therefore, that individuated interaction has no significant effect in the context of duty-free shops.

Fourth, we found that empowered interaction has a positive influence on rapport. That is, customers are more likely to establish a close relationship with salespersons when they shop. Specifically, this study aimed to examine the relationship between empowered interaction and rapport in the context of duty-free shops. In this regard, this study provides a critical theoretical contribution to the current body of literature.

Fifth, this study proposed that concerted interaction has a significant impact on rapport. This finding can be interpreted as follows: If salespersons work together seamlessly when selling products, then customers will enjoy interacting with them. This study further expanded our understanding of the role of concerted interaction by empirically determining its effect on rapport in the context of duty-free shops.

Sixth, the results of this study also showed that developmental interaction has a positive influence on rapport. This finding is consistent with those of previous studies [31,59], which have suggested that developmental interaction is a vital part of employee service quality. That is, when customers perceive that a salesperson is knowledgeable about his or her job, they are more likely to develop a harmonious relationship with that salesperson.

Seventh, this study found that rapport has a positive influence on customer satisfaction and brand preference, which in turn positively affects word-of-mouth exchanges. When customers have a good relationship with a salesperson, they are satisfied with and prefer duty-free shops. Furthermore, they are likely to recommend the duty-free shop to others. The current study empirically confirms this argument by using data collected from the 
context of duty-free shops. This aspect of the present study represents a unique contribution to previous research and offers important theoretical implication.

Lastly, the data analysis result indicated that brand preference has a positive influence on word-of-mouth (Hypothesis 11), suggesting that when customers prefer a certain brand, they are more likely to say positive words about the brand. In this regard, this study extended the existing relationship with the tourism industry, which is considered an important implication of this study.

\subsection{Practical Implications}

The results of this study also have the following managerial implications. First, the data analysis result indicated the effect of relational interaction on rapport. Thus, salespersons should exert an effort to create a comfortable atmosphere when talking with customers. For instance, it is important that a salesperson is attentive to what customers are saying. In addition, we recommend that employees converse with customers in a friendly manner. An example of how to achieve this in practice would be to provide salespersons with an etiquette education program so that they are better equipped to engage in friendly conversation with customers.

Second, this study found that there is positive relationship between ethical interaction and rapport. It is therefore recommended that managers in duty-free shops should provide internal staff training that aims to enhance salespersons' moral and ethical thinking.

Third, the data analysis result revealed that empowered interaction aids to enhance rapport. This finding has managerial implications as well. Salespersons should strive to meet customer requirements. For instance, a salesperson should recommend products that are appropriate for their customers after identifying the customers' personal preferences, rather than merely offering popular products.

Fourth, the current study confirmed the relationship between concerted interaction and rapport. The results imply that the sharing of roles is very important for salespersons because duty-free shops can, at certain times, become very crowded. Therefore, it is important that salespersons understand each other's role and strengthen cooperation in order to promote the formation of an effective and efficient working environment.

Fifth, the result of data analysis indicated the effect of developmental interaction on rapport. This makes it very important to develop a well-organized training system to enhance salespersons' job knowledge. Moreover, the provision of such training can exert a positive influence on employee job satisfaction, which decreases turnover intentions [111].

\subsection{Limitations and Future Lines of Research}

The findings of this study carry significant theoretical and practical implications. However, the study also suffers from the following limitations. First, this study focused exclusively on the experiences of Chinese tourists who had visited Korea. Thus, the results cannot be generalized to other regions or to people of different nationalities. Second, this study focused only on duty-free shops. It is necessary that further research be carried out on the basis of other types of stores to see whether the findings are replicated in other settings. Third, future studies that apply the proposed model of this study need to include consideration of demographic characteristics as a moderating or control variable because consumer shopping behaviors differ according to such characteristics (e.g., age and gender) [112,113]. Lastly, this study is limited because of its method of data collection, which involved the use of an online survey rather than a filed survey. That said, online surveys do offer certain advantages, for example, in terms of cost-effectiveness and timeeffectiveness, the selection of targeted samples, and a user-friendly platform [102].

Author Contributions: Conceptualization, J.H. and K.-W.L.; methodology, J.H. and K.-W.L. software, J.H. and K.-W.L.; validation, J.H.; formal analysis, J.H. and K.-W.L.; investigation, J.H. and K.-W.L.; resources, J.H.; data curation, J.H. and K.-W.L.; writing-original draft preparation, J.H., K.-W.L., and S.S.K.; writing-review and editing, J.H., K.-W.L., and S.S.K. All authors have read and agreed to the published version of the manuscript. 
Funding: This publication was supported by Daegu University Research Grants in 2019.

Institutional Review Board Statement: Not applicable.

Informed Consent Statement: Not applicable.

Data Availability Statement: Data sharing not applicable.

Conflicts of Interest: The authors declare no conflict of interest.

\section{References}

1. China Tourism Academy. Annual Report of China Outbound Tourism Development 2014; China Tourism Academy: Beijing, China, 2014.

2. Lin, W.T.; Chen, C.Y. Shopping satisfaction at airport duty-free stores: A cross-cultural comparison. J. Hosp. Mark. Manag. 2013, 22, 47-66. [CrossRef]

3. The Korea Herald. Duty-free Business Becomes Cash Cow Only for Bigger Players 2019. Available online: http://www. koreaherald.com/view.php?ud=20190506000105 (accessed on 25 August 2020).

4. Asia Economic. Highest Amount of Sales in Duty Free Shops Despite Less Spending of Inbound Tourists 2019. Available online: https: / / www.asiae.co.kr/article/2019061811110688568 (accessed on 10 June 2020).

5. Park, J.W.; Choi, Y.J.; Moon, W.C. Investigating the effects of sales promotions on customer behavioral intentions at duty-free shops: An Incheon International Airport case study. J. Airl. Airpt. Manag. 2013, 3, 18-30. [CrossRef]

6. Biedenbach, G.; Bengtsson, M.; Wincent, J. Brand equity in the professional service context: Analyzing the impact of employee role behavior and customer-employee rapport. Ind. Mark. Manag. 2011, 40, 1093-1102. [CrossRef]

7. Campbell, K.S.; Davis, L.; Skinner, L. Rapport management during the exploration phase of the salesperson-customer relationship. J. Pers. Sell. Sales Manag. 2006, 26, 359-370. [CrossRef]

8. Bettencourt, L.A.; Brown, S.W. Contact employees: Relationships among workplace fairness, job satisfaction and prosocial service behaviors. J. Retail. 1997, 73, 39-61. [CrossRef]

9. Brady, M.K.; Cronin, J.J., Jr. Customer orientation: Effects on customer service perceptions and outcome behaviors. J. Serv. Res. 2001, 3, 241-251. [CrossRef]

10. Hall, J.A.; Roter, D.L.; Blanch, D.C.; Frankel, R.M. Observer-rated rapport in interactions between medical students and standardized patients. Patient Educ. Couns. 2009, 76, 323-327. [CrossRef] [PubMed]

11. Gremler, D.D.; Gwinner, K.P. Customer-employee rapport in service relationships. J. Serv. Res. 2000, 3, 82-104. [CrossRef]

12. Karpen, I.O.; Bove, L.L.; Lukas, B.A.; Zyphur, M.J. Service-dominant orientation: Measurement and impact on performance outcomes. J. Retail. 2015, 91, 89-108. [CrossRef]

13. Solnet, D.; Kandampully, J. How some service firms have become part of "service excellence" folklore. Manag. Serv. Qual. Int. J. 2008. [CrossRef]

14. Hennig-Thurau, T.; Groth, M.; Paul, M.; Gremler, D.D. Are all smiles created equal? How emotional contagion and emotional labor affect service relationships. J. Mark. 2006, 70, 58-73. [CrossRef]

15. Tickle-Degnen, L.; Rosenthal, R. Group rapport and nonverbal behavior. In Review of Personality and Social Psychology; Hendrick, C., Ed.; Sage Publications: Thousand Oaks, CA, USA, 1987; Volume 9, pp. 113-136.

16. Dell Sherry, A. Relational Communication and Organizational Customer Loyalty. Ph.D. Thesis, University of Denver, Denver, CO, USA, 1992.

17. LaBahn, D.W. Advertiser perceptions of fair compensation, confidentiality, and rapport. J. Advert. Res. 1996, 36, $28-39$.

18. Catt, S.; Miller, D.; Schallenkamp, K. You are the key: Communicate for learning effectiveness. Education 2007, 127, $369-378$.

19. DeWitt, T.; Brady, M.K. Rethinking service recovery strategies: The effect of rapport on consumer responses to service failure. J. Serv. Res. 2003, 6, 193-207. [CrossRef]

20. Surprenant, C.F.; Solomon, M.R. Predictability and personalization in the service encounter. J. Mark. 1987, 51, 86-96. [CrossRef]

21. Cronin, J.J., Jr.; Taylor, S.A. Measuring service quality: A reexamination and extension. J. Mark. 1992, 56, 55-68. [CrossRef]

22. Coupland, J. Small talk: Social functions. Res. Lang. Soc. Interact. 2003, 36, 1-6. [CrossRef]

23. Morgan, R.M.; Hunt, S.D. The commitment-trust theory of relationship marketing. J. Mark. 1994, 58, 20-38. [CrossRef]

24. Gremler, D.D.; Gwinner, K.P. Rapport-building behaviors used by retail employees. J. Retail. 2008, 84, 308-324. [CrossRef]

25. Reid, D.A.; Plank, R.E.; Minton, A.P. Industrial buyers' assessments of sales behaviors. J. Mark. Manag. $1997,7$.

26. Lakin, J.L.; Chartrand, T.L. Using nonconscious behavioral mimicry to create affiliation and rapport. Psychol. Sci. 2003, 14, 334-339. [CrossRef] [PubMed]

27. Kim, W.; Ok, C.; Gwinner, K.P. The antecedent role of customer-to-employee relationships in the development of customer-to-firm relationships. Serv. Ind. J. 2010, 30, 1139-1157. [CrossRef]

28. Hartline, M.D.; Ferrell, O.C. The management of customer-contact service employees: An empirical investigation. J. Mark. 1996, 60, 52-70. [CrossRef]

29. Chen, P.T.; Hu, H.H. The effect of relational benefits on perceived value in relation to customer loyalty: An empirical study in the Australian coffee outlets industry. Int. J. Hosp. Manag. 2010, 29, 405-412. [CrossRef] 
30. Hennig-Thurau, T.; Gwinner, K.P.; Gremler, D.D. Understanding relationship marketing outcomes: An integration of relational benefits and relationship quality. J. Serv. Res. 2002, 4, 230-247. [CrossRef]

31. Karpen, I.O.; Bove, L.L.; Lukas, B.A. Linking service-dominant logic and strategic business practice: A conceptual model of a service-dominant orientation. J. Serv. Res. 2012, 15, 21-38. [CrossRef]

32. Dong, B.; Evans, K.R.; Zou, S. The effects of customer participation in co-created service recovery. J. Acad. Mark. Sci. 2008, 36, 123-137. [CrossRef]

33. Lusch, R.F.; Vargo, S.L.; Tanniru, M. Service, value networks and learning. J. Acad. Mark. Sci. 2010, 38, 19-31. [CrossRef]

34. Vargo, S.L.; Lusch, R.F. Service-dominant logic: Continuing the evolution. J. Acad. Mark. Sci. 2008, 36, 1-10. [CrossRef]

35. Vargo, S.L.; Akaka, M.A. Service-dominant logic as a foundation for service science: Clarifications. Serv. Sci. 2009, 1, 32-41. [CrossRef]

36. Macintosh, G. Customer orientation, relationship quality, and relational benefits to the firm. J. Serv. Mark. 2007, 21, 150-159. [CrossRef]

37. Hunt, S.D.; Lambe, C.J. Marketing's contribution to business strategy: Market orientation, relationship marketing and resourceadvantage theory. Int. J. Manag. Rev. 2000, 2, 17-43. [CrossRef]

38. Mavondo, F.T.; Rodrigo, E.M. The effect of relationship dimensions on interpersonal and interorganizational commitment in organizations conducting business between Australia and China. J. Bus. Res. 2001, 52, 111-121. [CrossRef]

39. Schneider, B.; Bowen, D.E. Winning the service game. In Handbook of Service Science; Springer: Boston, MA, USA, 2010; pp. 31-59.

40. Olkkonen, R.; Tikkanen, H.; Alajoutsijärvi, K. The role of communication in business relationships and networks. Manag. Decis. 2000, 38, 403-409. [CrossRef]

41. Boshoff, C. RECOVSAT: An instrument to measure satisfaction with transaction-specific service recovery. J. Serv. Res. 1999, 1, 236-249. [CrossRef]

42. Gremler, D.D.; Gwinner, K.P.; Brown, S.W. Generating positive word-of-mouth communication through customer-employee relationships. Int. J. Serv. Ind. Manag. 2001, 12, 44-59. [CrossRef]

43. King, B.; Dwyer, L.; Prideaux, B. An evaluation of unethical business practices in Australia's China inbound tourism market. Int. J. Tour. Res. 2006, 8, 127-142. [CrossRef]

44. Geyskens, I.; Steenkamp, J.B.E.; Kumar, N. Generalizations about trust in marketing channel relationships using meta-analysis. Int. J. Res. Mark. 1998, 15, 223-248. [CrossRef]

45. Australian Tourism Export Council. "Rogue" Operator Problem Tackled at Gold Coast Workshop. 2005. Available online: http: / / www.atec.net.au/MediaRelease_Rogue_operator_problem_tackled_at_Gold_Coast_Workshop.htm (accessed on 23 May 2016).

46. Han, H.; Yu, J.; Lee, K.S.; Baek, H. Impact of corporate social responsibilities on customer responses and brand choices. J. Travel Tour. Mark. 2020, 37, 302-316. [CrossRef]

47. Han, H.; Koo, B.; Hyun, S.S. Image congruity as a tool for traveler retention: A comparative analysis on South Korean full-service and low-cost airlines. J. Travel Tour. Mark. 2020, 37, 347-360. [CrossRef]

48. Sheth, J.N.; Sisodia, R.S.; Sharma, A. The antecedents and consequences of customer-centric marketing. J. Acad. Mark. Sci. 2000, 28, 55-66. [CrossRef]

49. Gremler, D.D.; Rinaldo, S.B.; Kelley, S.W. Rapport-Building Strategies Used by Service Employees: A Critical Incident Study; Conference Proceedings; American Marketing Association: Chicago, IL, USA, 2002; p. 73.

50. Bitner, M.J.; Booms, B.H.; Tetreault, M.S. The service encounter: Diagnosing favorable and unfavorable incidents. J. Mark. 1990, 54, 71-84. [CrossRef]

51. Price, L.L.; Arnould, E.J.; Deibler, S.L. Consumers' emotional responses to service encounters: The influence of the service provider. Int. J. Serv. Ind. Manag. 1995, 6, 34-63. [CrossRef]

52. Jacobs, R.S.; Hyman, M.R.; McQuitty, S. Exchange-specific self-disclosure, social self-disclosure, and personal selling. J. Mark. Theory Pract. 2001, 9, 48-62. [CrossRef]

53. Normann, R.; Ramirez, R. From value chain to value constellation: Designing interactive strategy. Harv. Bus. Rev. 1993, 71, 65-77.

54. Kalaignanam, K.; Varadarajan, R. Customers as co-producers. In The Service-Dominant Logic of Marketing: Dialog, Debate, and Directions; Routledge: Milton Park, UK, 2006; pp. 166-179.

55. Prahalad, C.K.; Ramaswamy, V. Co-creation experiences: The next practice in value creation. J. Interact. Mark. 2004, 18, 5-14. [CrossRef]

56. Kang, J.; Hyun, S.S. Effective communication styles for the customer-oriented service employee: Inducing dedicational behaviors in luxury restaurant patrons. Int. J. Hosp. Manag. 2012, 31, 772-785. [CrossRef]

57. Flint, D.J.; Mentzer, J.T. Striving for Integrated Value Chain Management Given a Service-Dominant: The Service-Dominant Logic of Marketing: Dialog, Debate, and Directions; ME Sharpe: Armonk, NY, USA, 2006; pp. 139-149.

58. Ganesan, S.; Hess, R. Dimensions and levels of trust: Implications for commitment to a relationship. Mark. Lett. 1997, 8, 439-448. [CrossRef]

59. Martínez, P.; Del Bosque, I.R. CSR and customer loyalty: The roles of trust, customer identification with the company and satisfaction. Int. J. Hosp. Manag. 2013, 35, 89-99. [CrossRef]

60. Han, H.; Lee, K.S.; Chua, B.L.; Lee, S. Contribution of airline F\&B to passenger loyalty enhancement in the full-service airline industry. J. Travel Tour. Mark. 2020, 37, 380-395. 
61. Gremler, D.D.; Brown, S.W. January, Service Loyalty: Antecedents, Components, and Outcomes; Conference Proceedings; American Marketing Association: Chicago, IL, USA, 1998; p. 165.

62. Bahadur, W.; Khan, A.N.; Ali, A.; Usman, M. Investigating the effect of employee empathy on service loyalty: The mediating role of trust in and satisfaction with a service employee. J. Relatsh. Mark. 2020, 19, 229-252. [CrossRef]

63. Kiyani, T.M.; Niazi, M.R.; Rizvi, R.; Khan, I. The relationship between brand trust, customer satisfaction and customer loyalty (evidence from automobile sector of Pakistan). Interdiscip. J. Contemp. Res. Bus. 2012, 4, 489-502.

64. Brown, T.J.; Barry, T.E.; Dacin, P.A.; Gunst, R.F. Spreading the word: Investigating antecedents of consumers' positive word-ofmouth intentions and behaviors in a retailing context. J. Acad. Mark. Sci. 2005, 33, 123-138. [CrossRef]

65. Chua, B.L.; Kim, H.C.; Lee, S.; Han, H. The role of brand personality, self-congruity, and sensory experience in elucidating sky lounge users' behavior. J. Travel Tour. Mark. 2019, 36, 29-42. [CrossRef]

66. Keller, K.L. Building Customer-Based Brand Equity: A Blueprint for Creating Strong Brands; Marketing Science Institute: Cambridge, MA, USA, 2001; pp. 3-27.

67. Aaker, D.A. Measuring brand equity across products and markets. Calif. Manag. Rev. 1996, 50, 102. [CrossRef]

68. Pitta, D.A.; Prevel Katsanis, L. Understanding brand equity for successful brand extension. J. Consum. Mark. 1995, 12, 51-64. [CrossRef]

69. Hellier, P.K.; Geursen, G.M.; Carr, R.A.; Rickard, J.A. Customer repurchase intention: A general structural equation model. Eur. J. Mark. 2003, 37, 1762-1800. [CrossRef]

70. Gensch, D.H. Empirically testing a disaggregate choice model for segments. J. Mark. Res. 1985, 22, 462-467. [CrossRef]

71. Roberts, J.H.; Lattin, J.M. Development and testing of a model of consideration set composition. J. Mark. Res. 1991, 28, 429-440. [CrossRef]

72. Mathur, A.; Moschis, G.P.; Lee, E. Life events and brand preference changes. J. Consum. Behav. 2003, 3, 129-141. [CrossRef]

73. Hwang, J.; Hyun, S.S. First-class airline travellers' perception of luxury goods and its effect on loyalty formation. Curr. Issues Tour. 2017, 20, 497-520. [CrossRef]

74. Berry, L.L. Relationship marketing of services-Growing interest, emerging perspectives. J. Acad. Mark. Sci. 1995, 23, 236-245. [CrossRef]

75. Reynolds, K.E.; Beatty, S.E. Customer benefits and company consequences of customer-salesperson relationships in retailing. J. Retail. 1999, 75, 11-32. [CrossRef]

76. Kim, K.; Baker, M.A. How the employee looks and looks at you: Building customer-employee rapport. J. Hosp. Tour. Res. 2019, 43, 20-40. [CrossRef]

77. Allen, N.J.; Grisaffe, D.B. Employee commitment to the organization and customer reactions: Mapping the linkages. Hum. Resour. Manag. Rev. 2001, 11, 209-236. [CrossRef]

78. Lehto, X.Y.; Chen, S.Y.; Silkes, C. Tourist shopping style preferences. J. Vacat. Mark. 2014, 20, 3-15. [CrossRef]

79. Sohn, H.K.; Lee, T.J. Tourists' impulse buying behavior at duty free shops: The moderating effects of time pressure and shopping involvement. J. Travel Tour. Mark. 2017, 34, 341-356. [CrossRef]

80. Söderlund, M. Customer satisfaction and its consequences on customer behaviour revisited: The impact of different levels of satisfaction on word-of-mouth, feedback to the supplier and loyalty. Int. J. Serv. Ind. Manag. 1998, 9, 169-188. [CrossRef]

81. Westbrook, R.A. Product/consumption-based affective responses and postpurchase processes. J. Mark. Res. 1987, 24, 258-270. [CrossRef]

82. Harrison-Walker, L.J. The measurement of word-of-mouth communication and an investigation of service quality and customer commitment as potential antecedents. J. Serv. Res. 2001, 4, 60-75. [CrossRef]

83. Han, H.; Kiatkawsin, K.; Jung, H.; Kim, W. The role of wellness spa tourism performance in building destination loyalty: The case of Thailand. J. Travel Tour. Mark. 2018, 35, 595-610. [CrossRef]

84. Chang, H.H.; Wong, K.H.; Fang, P.W. The effects of customer relationship management relational information processes on customer-based performance. Decis. Support. Syst. 2014, 66, 146-159. [CrossRef]

85. Wu, P.C.; Wang, Y.C. The influences of electronic word-of-mouth message appeal and message source credibility on brand attitude. Asia Pac. J. Mark. Logist. 2011, 23, 448-472. [CrossRef]

86. Hennig-Thurau, T.; Walsh, G.; Walsh, G. Electronic word-of-mouth: Motives for and consequences of reading customer articulations on the Internet. Int. J. Electron. Commer. 2003, 8, 51-74. [CrossRef]

87. Garbarino, E.; Johnson, M.S. The different roles of satisfaction, trust, and commitment in customer relationships. J. Mark. 1999, 63, 70-87. [CrossRef]

88. De Matos, C.A.; Rossi, C.A.V. Word-of-mouth communications in marketing: A meta-analytic review of the antecedents and moderators. J. Acad. Mark. Sci. 2008, 36, 578-596. [CrossRef]

89. Kozinets, R.V.; De Valck, K.; Wojnicki, A.C.; Wilner, S.J. Networked narratives: Understanding word-of-mouth marketing in online communities. J. Mark. 2010, 74, 71-89. [CrossRef]

90. Bolton, R.N.; Drew, J.H. A multistage model of customers' assessments of service quality and value. J. Consum. Res. 1991, 17, 375-384. [CrossRef]

91. Holbrook, M.B.; Corfman, K.P. Quality and value in the consumption experience: Phaedrus rides again. In Perceived Quality; Jacoby, J., Olson, J., Eds.; Lexington: Lexington, MA, USA, 1985; pp. 31-57. 
92. Zhou, L.; Wong, A. Exploring the influence of product conspicuousness and social compliance on purchasing motives of young Chinese consumers for foreign brands. J. Consum. Behav. 2008, 7, 470-483. [CrossRef]

93. Kim, W.; Ok, C.; Canter, D.D. Contingency variables for customer share of visits to full-service restaurant. Int. J. Hosp. Manag. 2010, 29, 136-147. [CrossRef]

94. Keiningham, T.L.; Perkins-Munn, T.; Aksoy, L.; Estrin, D. Does customer satisfaction lead to profitability? The mediating role of share of wallet. Manag. Serv. Qual. 2005, 15, 172-181. [CrossRef]

95. Hwang, J. Brand Preference and Its Impacts on Customer Share of Visits and Word-of-Mouth Intention: An Empirical Study in the Full-Service Restaurant Segment. Ph.D. Thesis, Kansas State University, Manhattan, KS, USA, 2011.

96. Kim, W.G.; Han, J.S.; Lee, E. Effects of relationship marketing on repeat purchase and word of mouth. J. Hosp. Tour. Res. 2001, 25, 272-288. [CrossRef]

97. Zhang, J.; Bloemer, J.M. The impact of value congruence on consumer-service brand relationships. J. Serv. Res. 2008, 11, 161-178. [CrossRef]

98. Kim, D.; Magnini, V.P.; Singal, M. The effects of customers' perceptions of brand personality in casual theme restaurants. Int. J. Hosp. Manag. 2011, 30, 448-458. [CrossRef]

99. Kim, W.; Ok, C. Customer orientation of service employees and rapport: Influences on service-outcome variables in full-service restaurants. J. Hosp. Tour. Res. 2010, 34, 34-55. [CrossRef]

100. Oliver, R.L. A cognitive model of the antecedents and consequences of satisfaction decisions. J. Mark. Res. 1980, 17, 460-469. [CrossRef]

101. Kim, W.; Ok, C.; Canter, D.D. Value-driven customer share of visits. Serv. Ind. J. 2012, 32, 37-58. [CrossRef]

102. Granello, D.H.; Wheaton, J.E. Online data collection: Strategies for research. J. Couns. Dev. 2004, 82, 387-393. [CrossRef]

103. Zikmund, W.G. Business Research Methods; Thomson/South Western: Mason, OH, USA, 2003.

104. Korea Duty Free Shops Association. Korea Tourism Statistics. Available online: http://www.kdfa.or.kr/ko/dutyfree/search.php (accessed on 4 July 2019).

105. Bagozzi, R.P.; Yi, Y. On the evaluation of structural equation models. J. Acad. Mark. Sci. 1988, 16, 74-94. [CrossRef]

106. Hair, J.F.; Black, W.C., Jr.; Babin, B.J.; Anderson, R.E.; Tatham, R.L. Multivariate Data Analysis, 6th ed.; Prentice-Hall: Upper Saddle River, NJ, USA, 2006.

107. Fornell, C.; Larcker, D.F. Structural equation models with unobservable variables and measurement error: Algebra and statistics. J. Mark. Res. 1981, 18, 382-388. [CrossRef]

108. Chi, C.G.Q.; Wen, B.; Ouyang, Z. Developing relationship quality in economy hotels: The role of perceived justice, service quality, and commercial friendship. J. Hosp. Mark. Manag. 2020, 29, 1027-1051. [CrossRef]

109. Ahmad, N.; Iqbal, N.; Javed, K.; Hamad, N. Impact of organizational commitment and employee performance on the employee satisfaction. Int. J. Learn. Teach. Educ. Res. 2014, 1, 84-92.

110. Hwang, J.; Han, H.; Kim, S. How can employees engage customers? Int. J. Contemp. Hosp. Manag. 2015, 27, 1117-1134. [CrossRef]

111. Arnett, D.B.; Laverie, D.A.; McLane, C. Using job satisfaction and pride as internal satisfaction. Cornell Hotel Restaur. Adm. Q. 2002, 43, 87-96. [CrossRef]

112. Fang, J.; Wen, C.; George, B.; Prybutok, V.R. Consumer heterogeneity, perceived value, and repurchase decision-making in online shopping: The role of gender, age, and shopping motives. J. Electron. Commer. Res. 2016, 17, 116.

113. Hernández, B.; Jiménez, J.; José Martín, M. Age, gender and income: Do they really moderate online shopping behaviour? Online Inf. Rev. 2011, 35, 113-133. [CrossRef] 